\title{
Geriatrik popülasyonda kolestatik karaciğer hastalıklarında etiyoloji ve tanısal yaklaşım: 185 vakalık tek merkez deneyimi
}

\author{
Etiology and diagnosis of cholestatic liver diseases in the geriatric population: A single-center \\ experience of 185 cases
}

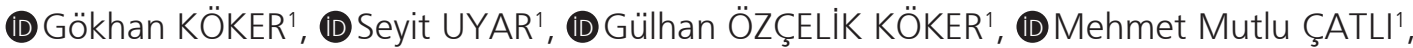 \\ (D) Yasin ŞAHINTÜRK', D Feyzi BOSTAN'¹, (D)Ayhan Hilmi ÇEKIN²
}

Sağlık Bilimleri Üniversitesi Antalya Eğitim ve Araştırma Hastanesi ${ }^{1} \mid{ }_{c ̧}$ Hastalıkları Kliniği, ${ }^{2}$ Gastroenteroloji Kliniği, Antalya

\begin{abstract}
Giriş ve Amaç: Kolestaz etiyolojik nedenlerinin ve klinik bulgularının 65 yaş üstü hastalarda geniş hasta popülasyonu ile dökümante edilmesi amaçlandı. Gereç ve Yöntem: Kolestaz nedeniyle yatışı yapılan 65 yaş ve üstü hastalar retrospektif olarak şikayetleri, laboratuvar parametreleri ve görüntüleme sonuçlarına göre değerlendirildi. Benign ve malign etiyolojik nedenler olarak iki gruba ayrilan hastalarda malignite göstergesi olabilecek parametreler için ileri analiz yapıldı. Bulgular: ÇaIışmamıza retrospektif olarak 65 yaş ve üstü 185 hasta dahil edildi. 109 (\%58.9) hastanın etiyolojisi benign, 69 (\%37.3) hastanın malign nedenlere bağlı olarak saptandı. 56 hastada (\%30.3) koledokolitiazis, 25 hastada (\%13.5) kolanjioselüler karsinom, 23 hastada (\%12.4) pankreas kanseri en sık görülen tanılardı. En sık başvuru şikayeti karın ağrısıydı. Sarılık şikayetiyle başvuran hastaların \%45.6'sı (n: 52) benign, \%54.4'ü (n: 62) malign iken kilo kaybıyla başvuran hastaların \%6.2'si benign, \%93.8'i maligndi. Sarılık ve/veya kilo kaybı şikayetiyle başvuran hastaların malign olma ihtimali istatistiksel olarak anlamlı düzeyde yüksek saptandı $(p<0.001)$. Çok değişkenli analiz sonuçlarına göre total bilirübin ve alkalen fosfatazın diğer değişkenlerden bağımsız olarak malignite ile pozitif olarak ilişkili olduğu görüldü. Ultrasonografi ile 185 hastanın $85^{\prime i n e ~(\% 46) ~ t a n ı ~ k o y u l a b i l i r k e n, ~ 100 ' u ̈ n e ~(\% 54) ~ i s e ~ t a n ı ~ k o y u l a m a d ı g ̆ ı ~}$ görülmüştür. Sonuç: Geriatrik popülasyonda kolestaz etiyolojisinde benign sebepler daha sık görülmüştür. Sarllık ve kilo kaybı şikayetleri olan ve/veya bilirübin ve alkalen fosfataz düzeyi yüksek olan hastalarda ise malign hastalıklar ayırıcı tanıda öncelikli olmalıdır. Ultrasonografi geriatrik popülasyondaki kolestazlı hastalarda tanı koymada yetersiz bulunmuş, ileri görüntüleme tetkiklerine ihtiyaç duyulmuştur.
\end{abstract}

Anahtar kelimeler: Kolestaz, geriatrik popülasyon, sarılık, benign/malign etiyoloji, koledokolitiazis, kolanjioselüler kanser

\section{GíRiş}

Kolestaz, terim olarak Yunanca kökenlidir ve safra akışının durması anlamına gelir (1). Safranın oluşumu ve atılımı hayati bir fonksiyondur. İlaçlar, enfeksiyonlar, otoimmün, metabolik ve genetik hastalıklar neticesinde safranın oluşumunda ve/veya safra akımındaki bozukluk sonucunda gelişen kaşıntı, halsizlik ve genelde eşlik eden sarılık ile karakterize klinik tablo kolestaz olarak tanımla-

iletişim: Gökhan KÖKER

Sağlık Bilimleri Üniversitesi Antalya Eğitim ve Araştırma Hastanesi, Iç Hastalıkları Kliniği, Muratpaşa/Antalya

E-mail: gkhnkkr@hotmail.com
Background and Aims: In this study, we aimed to analyze the etiology of cholestasis in a large geriatric patient population according to their complaints, laboratory parameters, and imaging results. Materials and methods: A total of 185 geriatric patients (age: > 65 years) with cholestasis were included in this retrospective study. The patients were divided into two groups, i.e., benign etiology and malignant etiology, in order to further analyze parameters that could indicate malignancy. Results: A total of 109 (58.9\%) patients had benign etiologies and 69 (37.3\%) had malignant etiologies. The most common etiologies were choledocholithiasis [56 patients (30.3\%)], cholangiocellular carcinoma [25 patients (13.5\%)], and pancreatic cancer [23 patients $(12.4 \%)]$. The chief complaint was abdominal pain. In patients with jaundice, benign diseases accounted for approximately $45.6 \%$ of etiologies, whereas malignant diseases accounted for approximately $54.4 \%$ of etiologies. In patients with weight loss, benign diseases accounted for approximately $6.2 \%$ of etiologies, whereas malignant diseases accounted for approximately $93.8 \%$ of etiologies. In addition, both conditions were statistically significant $(p<0.001)$. Multivariate regression analysis showed that total bilirubin and alkaline phosphatase were independent markers for malignant diseases. Ultrasonography correctly diagnosed only $46 \%$ of patients. Conclusion: Benign etiologies are the most frequent diagnosis for the management of cholestasis in the geriatric population. In patients with complaints of jaundice and weight loss and/or patients with high bilirubin and alkaline phosphatase levels, malignant diseases should be a priority in the differential diagnosis. Ultrasonography was inadequate in diagnosing cholestasis in the geriatric population, and further imaging studies are needed.

Key words: Cholestasis, geriatric population, jaundice, benign/malignant etiology, choledocholithiasis, cholangiocellular cancer

nır (2). Tanısal ve tedavi yaklaşımında kolaylık sağlanması amacıyla kolestaz intrahepatik ve ekstrahepatik olmak üzere iki ana grupta değerlendirilir. İntrahepatik kolestaz, hepatoselüler disfonksiyon ve intrahepatik safra yollarının obstrüksiyonlarına sekonder olarak gelişirken, ekstrahepatik kolestaz ise ana safra yollarında safra akımına engel olan patolojiler sonucunda gelişmektedir (3). Tüm has-

Köker G, Uyar S, Özçelik Köker G, et al. Etiology and diagnosis of cholestatic liver diseases in the geriatric population: A single-center experience of 185 cases. The Turkish Journal of Academic Gastroenterology 2021;20:94-103. DOI: $10.17941 /$ agd.980348

Geliş Tarihi: 25.02.2021 • Kabul Tarihi: 20.07.2021 
talıklarda olduğu gibi kolestazlı hastalara yaklaşımda da dikkatli bir anamnez ve fizik muayene tanıda önemli ipuçları verebilir (1). Kolestazdan şüphelenilen hastaların tanı, tedavi ve takiplerinde laboratuvar ve görüntüleme yöntemleri yol göstericidir (4). Kolestaz primer olarak mortalite ve morbidite sebebi değildir; fakat kolanjit, sepsis, akut böbrek hasarı ve santral sinir sistemi disfonksiyonu gibi ciddi komplikasyonları hastalığın mortal seyretmesine sebep olabilir (1).

Yaşlanma, birçok biyolojik yolun yavaşlaması ve/veya durmasıyla karakterize geri dönüşü olmayan fizyolojik bir süreçtir. Değişen fizyolojik yapı geriatrik popülasyonda birçok hastalığın etiyoloji ve epidemiyolojisinde farklılıklar yaratır (5). Dünya Sağlık Örgütü (DSÖ) verilerine göre 2016 yılı dünya nüfusunun \%12.5'ini yaşlı kişiler oluşturmaktadır (6). Geriatrik yaş grubundaki insanların, 2060 yılına gelindiğinde 3.25 kat artarak dünya nüfusunun \%29.7'sini oluşturacağı tahmin edilmektedir (7).

Geriatrik hasta grubunda hastaneye yatış oranları diğer yaş gruplarına göre artmıştır. Bozulan fizyolojik yapı ve artan ek hastalık oranları yaşlı hastalarda kolestazı önemli bir sağlık sorunu haline getirmektedir. Hızlı ve doğru tanı bu hastaların prognozlarında önemli rol oynar (8). Bu çalışmada kolestatik karaciğer hastalığı nedeniyle İç Hastalıkları ve Gastroenteroloji Kliniği'mize yatırılan 65 yaş ve üstü hastaların retrospektif olarak değerlendirilmesi ve etiyolojilerinin incelenmesi amaçlanmıştır.

\section{GEREÇ ve YÖNTEM}

Çalışmaya Sağlık Bilimleri Üniversitesi Antalya Eğitim ve Araştırma Hastanesi Dahiliye ve Gastroenteroloji Kliniği'ne Mayıs 2015-Mayıs 2017 tarihleri arasında kolestaz nedeni ile yatışı yapılan 65 yaş ve üstü hastalar dahil edilmiştir. Çalışmaya 91'i (\%49.2) kadın 94'ü (\%50.2) erkek olmak üzere toplam 185 hasta dahil edildi. Aynı zamanda hastalar; DSÖ'nün, yaşlılığı demografik anlamda sınıflandırmasına göre 65-74 yaş arası erken yaşlıık, 75-84 yaş arası yaşlıık, 85 yaş üzeri ise ileri yaşlılık olmak üzere 3 gruba ayrıldılar. Hastaların kolestaz tanısına eşlik eden kronik hastalıkları Diyabetes Mellitus (DM), hipertansiyon $(\mathrm{HT})$, koroner arter hastalığı $(\mathrm{KAH})$, epilepsi, konjestif kalp yetmezliği $(K K Y)$, hepatit B virüsü (HBV) enfeksiyonu, siroz, hepatit C virüsü (HCV) enfeksiyonu, kronik obstrüktif akciğer hastalığı (KOAH), serebrovasküler olay (SVO), malignite şeklinde ek hastalıklar olarak belirtildi. Hastaların demografik özellikleri, hastaneye başvuru şikayetleri, özgeçmiş özellikleri, total bilirübin, direkt bilirübin, aspartat aminotransferaz (AST), alanin aminotransferaz $(A L T)$, alkalen fosfataz (ALP), gama glutamil transferaz (GGT), laktat dehidrogenaz (LDH), sedimantasyon, C-re- aktif protein (CRP) gibi laboratuvar parametreleri, ultrasonografi (USG), magnetik rezonans (MR), bilgisayarlı tomografi (BT), endoskopik retrograd kolanjiopankreatografi (ERCP) gibi görüntüleme yöntemlerinin sonuçları, hastaların kolestaz etiyolojileri belirlenip hazırlanmış olan standart kayıt formlarına kaydedilmiştir. Bu veriler ışığında total bilirübin seviyesi $2 \mathrm{mg} / \mathrm{dl}$ ve üzerinde olan hastalar çalışmaya dahil edilmiştir. Total bilirübini 2 mg/dl'nin altında olanlar veya 65 yaş altında olan hastalar çalışmaya dahil edilmemiştir.

Tanımlayıcı istatistikler frekans, yüzde, ortalama (mean), standart sapma (SD) ve medyan (ortanca), minimum (min.), maksimum (maks.) değerleri ile sunulmuştur. Kategorik değişkenler arasındaki ilişkilerin analizinde Fisher's Exact Test veya Pearson ki-kare testi kullanılmıştır. Normallik testinde gruptaki örneklem sayısı 50'den küçük olduğunda Shapiro Wilks, büyük olduğunda Kolmogorov-Smirnov testi kullanılmıştır. İki grubun ölçüm değerleri arasındaki farkın analizinde normal dağılım varsayımının sağlanmadığı durumlarda Mann-Whitney U testi, sağlandığı durumlarda ise Student t testi kullanılmıştır. Üç veya daha fazla grubun parametrik olmayan karşılaştırmasında Kruskal Wallis testi, anlamlı çıkan durumlar için post-hoc test olarak Bonferroni-Dunn testi kullanılmıştır. Analizler SPSS 22.0 paket programı ile yapılmıştır. 0.05'den küçük p değerleri istatistiksel olarak anlamlı kabul edilmiştir.

\section{Etik Kurul Onayı}

Bu araştırma retrospektif olarak tasarlanmış klinik bir çalışmadır. Etik kurul onayı Sağlık Bilimleri Üniversitesi Antalya Eğitim ve Araştırma Hastanesi Etik Kurulu'ndan alınmıştır (Karar No: 24.03.2016/76-3).

\section{BULGULAR}

Çalışmaya 91'i kadın, 94'ü erkek olmak üzere 185 hasta dahil edildi. Erkeklerin kadınlara oranı 1:1.03 idi. Hastaların yaş ortalaması $76.5 \pm 7.5$ olarak hesaplandı. Hastaların \%56'sında kolestaz tanısına eşlik eden bir veya birden fazla ek hastalık vardı. Çalışma popülasyonunun karakteristik özellikleri Tablo 1'de özetlendi.

185 hastadan 178'inin kolestaz etiyolojisi saptanırken 7 'sinin kolestaz nedeni saptanamamıştır. Bu hastaların 3 tanesinin takiplerinde tamamen iyileştiği, 4 tanesinin ise hastanemizde bulunmaması üzerine endoskopik ultrasonografi (EUS) için başka bir merkeze yönlendirildiği saptandı. EUS için yönlendirilen hastaların çalışma esnasında tekrar hastanemize başvurmadığı görüldü. Bu 7 kişilik grup kolestaz etiyoloji kısmında etiyolojisi belirsiz olarak belirtildi. 
Tablo 1. Çalışma popülasyonunun karakteristik özellikleri

\begin{tabular}{|c|c|c|}
\hline & $n=185$ & $\%$ \\
\hline \multicolumn{3}{|l|}{ Cinsiyet } \\
\hline Kadın & 91 & 49.2 \\
\hline Erkek & 94 & 50.8 \\
\hline \multicolumn{3}{|c|}{ Yaş grubu } \\
\hline $65-74$ & 76 & 41.1 \\
\hline $75-84$ & 74 & 40 \\
\hline$>85$ & 35 & 18.9 \\
\hline \multicolumn{3}{|c|}{ Ek hastalık } \\
\hline Yok & 56 & 30.3 \\
\hline Var & 129 & 69.7 \\
\hline
\end{tabular}

Hastalar benign, malign ve etiyolojisi belirsiz olarak 3 gruba ayrıldığında; 109 (\%58.9) hastanın etiyolojisi benign, 69 (\%37.3) hastanın etiyolojisi malign, 7 (\%3.8) hastanın ise etiyolojisi belirsizdi. Hem malign hem de benign hastaların yaş ortalamaları 76 saptandı ve iki grubun yaş ortalaması arasındaki fark istatistiksel olarak anlamlı değildi $(p=0.995)$.

Hastalar benign ve malign olarak 2 gruba ayrıldığında ise 109 benign hastanın 56'sı kadın iken 53'ü erkekti. 69 malign hastanın ise $31^{\prime} \mathrm{i}$ kadın, 38'i erkekti. Cinsiyetin malign veya benign özelliklerle ilişkisi istatistiksel olarak anlamlı bulunmadı $(p=0.402)$. Benign ve malign hastaların yaş dağılımında istatistiksel olarak anlamlı farklılık saptanmadı $(p=0.917)$. Benign hastaların 81'ine (\%74.3) ek bir kronik hastalık eşlik ederken, malign hastların $45^{\prime}$ ine (\%65.2) ek bir kronik hastalığın eşlik ettiği görüldü ve bu istatistiksel olarak anlamlı değildi $(p=0.194)$.

Araştırmamızda kolestaza sebep olan tanılar incelendiğinde; 56'sının (\%30.3) koledokolitiazis, 25'inin (\%13.5) kolanjioselüler karsinom, 23'ünün (\%12.4) pankreas kanseri, $18^{\prime}$ inin (\%9.7) pankreatit, 14'ünün (\%7.6) siroz, 10'unun (\%5.4) hepatoselüler karsinom, 8'inin (\%4.3) periampüller tümör, 10'unun (\%5.4) sepsis, 4'ünün (\%2.2) ilaca bağlı kolestaz, 3'ünün (\%1.6) başka bir tümörün karaciğer metastazı, 3'ünün (\%1.6) HBV enfeksiyonu, 2'sinin (\%1.1) parazite bağlı kolestaz, 2'sinin (\%1.1) otoimmün hepatit olduğu saptandı. 7 (\%3.8) hastada ise kolestaza neden olan etiyoloji saptanamadı (Tablo 2). Kolestaz sebebini pankreatite bağladığımız hastaların kadın olma oranı istatistiksel olarak anlamlı düzeyde yüksek bulundu $(p=0.039)$ (Tablo 2$)$.

Etiyolojik nedenlerin kolestaz tiplerine göre intrahepatik ve ekstrahepatik olarak 2 gruba ayrılarak, benign ve malign olarak gruplandırıldığındaki dağııımı Tablo 3'te detayIı olarak verilmiştir.

\section{Tablo 2. Etiyolojkk sebepler ve hastaların dağlımı ( $n=185)$}

\begin{tabular}{|c|c|c|c|c|c|}
\hline \multirow[b]{2}{*}{ Etiyoloji } & \multirow[b]{2}{*}{$\begin{array}{c}\text { Tüm Hastalar } \\
n=185(\%)\end{array}$} & \multirow[b]{2}{*}{$\begin{array}{c}\text { Yaş } \\
\text { Ort } \pm \text { SS }\end{array}$} & \multicolumn{2}{|c|}{ Cinsiyet } & \multirow[b]{2}{*}{ p } \\
\hline & & & $\begin{array}{l}\text { Kadın } \\
\text { n (\%) }\end{array}$ & $\begin{array}{l}\text { Erkek } \\
\text { n (\%) }\end{array}$ & \\
\hline Koledokolitiazis & $56(30,3)$ & $76.85 \pm 7.39$ & $26(28.6)$ & $30(31.9)$ & 0.406 \\
\hline Kolanjioselüler karsinom & $25(13.5)$ & $79.2 \pm 7.71$ & $14(15.4)$ & $11(11.7)$ & 0.465 \\
\hline Pankreas kanseri & $23(12.4)$ & $74.13 \pm 6.98$ & $10(11)$ & $13(13.8)$ & 0.555 \\
\hline Pankreatit & $18(9.7)$ & $76.94 \pm 9.23$ & $13(14.3)$ & $5(5.3)$ & 0.039 \\
\hline Siroz & $14(7.6)$ & $75.57 \pm 6.9$ & $8(8.8)$ & $6(6.4)$ & 0.535 \\
\hline $\mathrm{HCC}$ & $10(5.4)$ & $77 \pm 7.97$ & $4(4.4)$ & $6(6.4)$ & 0.548 \\
\hline Sepsis & $10(5.4)$ & $74.63 \pm 6.7$ & $4(4.4)$ & $6(6.4)$ & 0.496 \\
\hline Periampuller tümör & $8(4.3)$ & $73.13 \pm 6.01$ & $2(2.2)$ & $6(6.4)$ & 0.161 \\
\hline İlaca bağlı & $4(2.2)$ & $76.25 \pm 6.8$ & $2(2.2)$ & $2(2.1)$ & 0.976 \\
\hline HBV & $3(1.6)$ & $69.67 \pm 6.43$ & $1(1.1)$ & $2(2.1)$ & 0.582 \\
\hline Metastaz & $3(1.6)$ & $80.67 \pm 5.51$ & $1(1.1)$ & $2(2.1)$ & 0.582 \\
\hline OIH & $2(1.1)$ & $72.5 \pm 9.19$ & $1(1.1)$ & $1(1.1)$ & 0.984 \\
\hline Parazit & $2(1.1)$ & $72.5 \pm 9.19$ & $1(1.1)$ & $1(1.1)$ & 0.298 \\
\hline Etiyoloji belirsiz & $7(3.8)$ & $77.14 \pm 9.82$ & $4(4.4)$ & $3(3.2)$ & 0.667 \\
\hline Toplam & $185(100)$ & & $91(49.2)$ & $94(50.8)$ & \\
\hline
\end{tabular}

HCC: Hepatoselüler karsinom, HBV: Hepatit B virüsü, OlH: Otoimmün hepatit. 


\section{Tablo 3. Etiyolojlk nedenlerin kolestaz tipine göre dağılımı ( $($ = 178)}

\begin{tabular}{|c|c|c|c|c|}
\hline \multicolumn{3}{|l|}{ Kolestaz Tipi } & $\mathrm{N}: 178$ & $\%$ \\
\hline \multirow{7}{*}{ İntrahepatik (n: 46) } & \multirow{5}{*}{ Benign (n: 33) } & Siroz & 14 & 7.9 \\
\hline & & İlaca bağlı & 4 & 2.2 \\
\hline & & Sepsis & 10 & 5.6 \\
\hline & & OIH & 2 & 1.1 \\
\hline & & HBV & 3 & 1.7 \\
\hline & \multirow{2}{*}{ Malign (n: 13) } & $\mathrm{HCC}$ & 10 & 5.6 \\
\hline & & Metastaz & 3 & 1.7 \\
\hline \multirow{6}{*}{ Ekstrahepatik (n: 132) } & \multirow{3}{*}{ Benign (n: 76) } & Koledokolitiasiz & 56 & 31.4 \\
\hline & & Pankreatit & 18 & 10.1 \\
\hline & & Parazit & 2 & 1.1 \\
\hline & \multirow{3}{*}{ Malign (n: 56) } & Pankreas kanseri & 23 & 12.9 \\
\hline & & Kolanjiyoselüler karsinom & 25 & 14 \\
\hline & & Periampuller tümör & 8 & 4.5 \\
\hline
\end{tabular}

OiH: Otoimmün hepatit, HBV: Hepatit B virüsü, HCC: Hepatoselüler karsinom.

Kolestaz etiyolojilerinin yaş gruplarına göre dağılımı incelendiğinde; 65-74 yaş aralığında en sık benign kolestaz sebebi koledokolitiazis (\%27.6) iken, en sık malign kolestaz sebebi pankreas kanseri (\%18.4) idi. 75-84 yaş arasında en sık benign kolestaz sebebi koledokolitiazis (\%31.9) iken, en sık malign kolestaz sebebi olarak kolanjioselüler kanser (\%16.2) saptandı. 85 yaş ve üzerinde ise en sık benign kolestaz sebebi koledokolitiazis (\%31.4) iken, en sık malign kolestaz sebebi kolanjiose- lüler kanser (\%17.1) olarak saptandı. Kolestaz saptanan 85 yaşından büyük 35 hastanın 20'sini (\%57) benign hastalıklar oluştururken, 13'ünü (\%43) malign hastalıklar oluşturuyordu. Kolestaz sebebi pankreas kanseri olan 23 hastanın yalnızca 3'ünün (\%13) yaşının 85'ten büyük olduğu görüldü. Kolestaz sebebi koledokolitiazis olan 56 hastanın sadece 11'inin (\%20.4) yaşının 85 yaş ve üzerinde olduğu görüldü. Söz konusu veriler Tablo 4 'te gösterilmiştir.

\section{Tablo 4. Malign ve benign etiyolojilerin yaş gruplarına göre dağılımı}

\begin{tabular}{|c|c|c|c|}
\hline \multirow[b]{2}{*}{ n: 185} & & Yaş & \\
\hline & $\begin{array}{c}65-74 \\
n: 76(\% 41)\end{array}$ & $\begin{array}{c}75-84 \\
n: 74(\% 40)\end{array}$ & $\begin{array}{c}>85 \\
\mathrm{n}: 35(\% 19)\end{array}$ \\
\hline Malign, n: 69 (37.3) & $29(38.2)$ & $27(36.4)$ & $13(37.1)$ \\
\hline Kolanjioselüler karsinom & $7(9.2)$ & $12(16.2)$ & $6(17.1)$ \\
\hline Periampuller tümör & $4(5.3)$ & $4(5.4)$ & $0(0)$ \\
\hline $\mathrm{HCC}$ & $4(5.3)$ & $3(4.1)$ & $3(8.6)$ \\
\hline Pankreas kanseri & $14(18.4)$ & $6(8.1)$ & $3(8.6)$ \\
\hline Metastaz & $0(0)$ & $2(2.7)$ & $1(2.9)$ \\
\hline Benign, n: 109 (58.9) & $43(56.5)$ & $46(62.2)$ & $20(57.2)$ \\
\hline Koledokolitiazis & $21(27.6)$ & $24(31.9)$ & $11(31.4)$ \\
\hline Pankreatit & $8(10.5)$ & $4(5.4)$ & $6(17.1)$ \\
\hline Sepsis & $3(3.9)$ & $5(6.8)$ & $2(5.8)$ \\
\hline Siroz & $7(9.2)$ & $6(8.1)$ & $1(2.9)$ \\
\hline HBV & $2(2.6)$ & $1(1.4)$ & $0(0)$ \\
\hline İlaca bağlı & $1(1.3)$ & $3(4.1)$ & $0(0)$ \\
\hline $\mathrm{OIH}$ & $1(1.3)$ & $1(1.4)$ & $0(0)$ \\
\hline Parazit & $0(0)$ & $2(2.7)$ & $0(0)$ \\
\hline Etiyoloji belirsiz, n: 7 (3.8) & $4(5.3)$ & $1(1.4)$ & $2(5.7)$ \\
\hline
\end{tabular}

HCC: Hepatoselüler karsinom, HBV: Hepatit B virüsü, OiH: Otoimmün hepatit. 
Hastaların hastaneye başvuru şikayetleri incelendiğinde 131 'inin (\%70.8) karın ağrısı, 118'inin (\%63.8) sarılık, 34'ünün (\%18.4) kaşıntı, 33'ünün (\%17.8) kilo kaybı, 32 'sinin (\%17.3) bulantı-kusma şikayetleri olduğu görüldü.

Sadece sarılık şikayetiyle başvuran hastaların sayısı 17 idi. Bunların 4'ü (\%23.5) kolanjioselüler karsinom, 4'ü (\%23.5) koledokolitiazis, 3'ü (\%17.6) pankreas kanseri, 2'si (\%11.8) periampüller tümör, 1'i (\%5.9) hepatoselüler karsinom, 1'i (\%5.9) HBV, 1'i (\%5.9) ilaca bağlı kolestazdı. Sadece sarılıkla başvuran 1 (\%5.9) hastanın ise kolestaz etiyolojisi saptanamadı. Sadece sarılık şikayetiyle başvuran hastalar benign ve malign şeklinde gruplandığında ise hastaların 10'unun (\%58.8) malign, 6'sının (\%35.3) benign olduğu görüldü.

Kilo kaybı ile başvuran 33 hasta incelendiğinde; 13'ünün (\%39.4) pankreas kanseri, 10'unun (\%30.3) kolanjioselüler karsinom, 2'sinin (\%6.1) karaciğer metastazı, 2'sinin (\%6.1) koledokolitiazis, 1'inin (\%3) pariampüller tümör olduğu saptandı. Kilo kaybı ile başvuran 1 (\%3) hastanın ise kolestaz etiyolojisi saptanamadı (Tablo 5). Kilo kaybı ile başvuran 33 hasta benign, malign ve etiyolojisi belirsiz olarak 3 gruba ayrıldığında ise hastaların 30'u (\%91) malign, 2'si (\%6) benign, 1'inin (\%3) ise etiyolojisi belirsizdi.

Hastalar benign ve malign olarak 2 gruba ayrıldıktan sonra şikayetlerine göre sınıflandırıldığında; karın ağrısı ile başvuran hastaların \%66.4'sı (n: 83) benign, \%33.6'sı (n: 42) ise maligndi. Karın ağrısı ile başvuran hastaların benign bir hastalık olma ihtimali malignlere göre istatistiksel olarak anlamlı düzeyde yüksek saptandı ( $p=0.030)$. Sarılık şikayetiyle başvuran hastaların \%45.6'sı (n: 52) benign, \%54.4'ü (n: 62) maligndi. Sarılık ile başvuran hastaların malign olma ihtimali istatistiksel olarak anlamlı

Tablo 5. Malign ve benign hastaların şikayetlerine göre sınıflandırılması

\begin{tabular}{|lcccc|}
\hline & & Benign & Malign & $\mathbf{p *}^{*}$ \\
\hline Karın ağrısı & Var & $83(76.1)$ & $42(60.8)$ & $\mathbf{0 . 0 3 0}$ \\
& Yok & $26(23.9)$ & $27(39.2)$ & \\
\hline Sarılık & Var & $52(47.7)$ & $62(89.8)$ & $<\mathbf{0 . 0 0 1}$ \\
\hline Kaşıntı & Yok & $57(52.3)$ & $7(10.2)$ & \\
\hline Kilo kaybı & Var & $16(14.6)$ & $18(26.1)$ & 0.059 \\
& Yok & $93(85.4)$ & $51(73.9)$ & \\
\hline Bulantı kusma & $2(1.9)$ & $30(43.4)$ & $<\mathbf{0 . 0 0 1}$ \\
& Yok & $107(98.1)$ & $39(56.6)$ & \\
& Yok & $22(20.1)$ & $9(13.1)$ & 0.221 \\
\hline
\end{tabular}

${ }^{*} p<0.05$ düzeyde yüksek saptandı ( $p<0.001$ ). Kilo kaybı ile başvuran hastaların \%6.2'si benign iken \%93.8'i maligndi. Kilo kaybı ile başvuran hastaların malign olma ihtimali istatistiksel olarak anlamlı düzeyde yüksek saptandı $(p<0.001)$ (Tablo 5).

Hastaların kolestaz etiyolojilerine göre ayrıldıktan sonra yatışının 1. günündeki tespit edilen laboratuvar değerlerine bakıldığında; en yüksek total bilirübin ortalamaları sırasıyla kolanjioselüler karsinom, pankreas kanseri, ilaca bağlı kolestaz ve periampuller tümörde saptanmıştır. En yüksek AST ve ALT değerleri HBV enfeksiyonunda iken, ALP özellikle malign hastalıklarda benign hastalıklara göre daha yüksek saptandı. En yüksek ALP değerleri kolanjioselüler karsinom, başka bir tümörün karaciğere metastazı, pankreas kanseri ve periampuller tümörde gözlendi. En yüksek GGT değerleri periampüller tümör, kolanjioselüler karsinom, başka bir tümörün karaciğere metastazı ve pankreas kanseri gibi malign sebeplerde görülebildiği gibi koledokolitiaziste de GGT değerleri ortalamaları yüksek saptandı. LDH yüksekliği en çok başka bir tümörün karaciğere metastazında ve parazitlere bağlı kolestazda gözlendi. En yüksek lökosit (WBC) değerleri koledokolitiazis ve pankreatit olgularında görüldü. Sedimantasyon değerinde en yüksek ortalamalar otoimmün hepatit olgularında saptandı. CRP ortalaması en yüksek olan kolestaz sebeplerinin ise pankreatit, metastaz ve koledokolitiazis oldukları görüldü.

Hastalar benign ve malign olarak sınıflandırılıp laboratuvar parametreleri karşılaştırıldı. Malign grubun total bilirübin, direkt bilirübin ve ALP değerleri benign gruba göre istatistiksel olarak anlamlı düzeyde yüksek bulundu ( $p=$ 0.001). Her iki grubun GGT değerleri karşılaştırıldığında malign grubun GGT ortalaması istatistiksel olarak anlamlı düzeyde yüksek bulundu ( $p=0.015)$. LDH ve CRP değerleri ortalaması ise benign grupta malign gruba kıyasla istatistiksel olarak anlamlı düzeyde yüksek saptandı (Tablo 6).

ALP'nin malign ve benign hastaları belirlemede ayırt edici faktör olup olmadığını belirlemek için ROC analizi yapıldı. ALP 399 U/L cut-off değeri için eğri altındaki alan (EAA) 0.784, total bilirübin $7 \mathrm{mg} / \mathrm{dl}$ cut-off değeri için EAA 0.808 ve direkt bilirübin 4.1 cut-off değeri için ise EAA 0.812 saptandı (Tablo 7). ALP, total bilirübin ve direkt bilirübin değerlerinin ROC eğrilerinin karşılaştırılması Şekil 1 'de gösterilmiştir.

Tek değişkenli analiz sonuçlarında anlamlı çıkan tüm değişkenler modele eklendiğinde total bilirübin ve ALP'nin diğer değişkenlerden bağımsız olarak malignite olma durumu ile pozitif olarak ilişkili olduğu görüldü (Tablo 8). 
Tablo 6. Benign ve malign grupların laboratuvar özelliklerinin karşılaştırılması $(n=178)$

\begin{tabular}{|c|c|c|c|}
\hline & \multicolumn{2}{|c|}{ Tanı } & \multirow[b]{2}{*}{ p } \\
\hline & $\begin{array}{l}\text { Benign } \\
\mathrm{n}: 109\end{array}$ & $\begin{array}{c}\text { Malign } \\
\mathrm{n}: 69\end{array}$ & \\
\hline Total bilirübin (mg/dl) & $4(2.1-23)$ & $12(2-31)$ & $0.001 * * *$ \\
\hline Direkt bilirübin (mg/dl) & $2.2(0.15-12)$ & $7.4(0.4-16)$ & $0.001 * * *$ \\
\hline AST (U/L) & $116(10-1970)$ & $128(34-602)$ & 0.425 \\
\hline $\operatorname{ALT}(\mathrm{U} / \mathrm{L})$ & $110(5-1326)$ & $89(12-756)$ & 0.558 \\
\hline $\operatorname{ALP}(U / L)$ & $227(46-1287)$ & $461(70-1678)$ & $0.001 * * *$ \\
\hline GGT (U/L) & $316(11-2300)$ & $430(43-1946)$ & $0.015^{*}$ \\
\hline LDH (U/L) & $297(128-1540)$ & $271(158-4738)$ & $0.049^{*}$ \\
\hline WBC $\left(/ \mathrm{mm}^{3}\right)$ & $8600(2400-73000)$ & $8600(2500-27000)$ & 0.258 \\
\hline Sedim. (mm/saat) & $36(2-120)$ & $35(4-100)$ & 0.998 \\
\hline CRP (mg/L) & $60(1-306)$ & $30(3-247)$ & $0.006^{* *}$ \\
\hline
\end{tabular}

AST: Aspartat aminotransferaz, ALT: Alanin aminotransferaz, ALP: Alkalen fosfataz. GGT: Gama glutamil transferaz, LDH: Laktat dehidrogenaz, WBC: Lökosit, Sedim: Sedimantasyon, CRP: C-reaktif protein.

Tablo 7. Malign kolestaz etiyolojilerinin tespiti için gereken ALP, total bilirübin, direkt bilirübin değerleri

\begin{tabular}{|l|c|c|c|c|}
\hline & \multicolumn{1}{|c|}{ EAA } & Cut-off değeri & Sensitivite (\%) & Spesifite (\%) \\
\hline ALP & $0.784,95 \% \mathrm{Cl}(0.716-0.842)$ & $399 \mathrm{U} / \mathrm{L}$ & 62.32 & 82.57 \\
\hline T. bilirübin & $0.808,95 \% \mathrm{Cl}(0.743-0.863)$ & $>7 \mathrm{mg} / \mathrm{dl}$ & 76.81 & 77.98 \\
\hline D. bilirübin & $0.812,95 \% \mathrm{Cl}(0.747-0.867)$ & $>4.1 \mathrm{mg} / \mathrm{dl}$ & 75.36 & 78.90 \\
\hline
\end{tabular}

EAA: Eğri altındaki alan, ALP: Alkalen fosfataz.

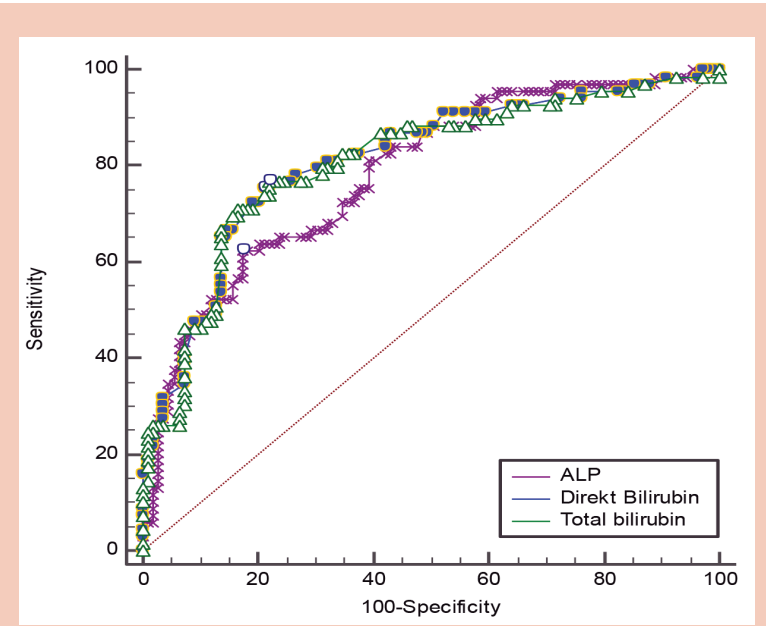

Şekil 1. ALP, total bilirübin ve direkt bilirübin değerlerinin ROC eğrilerinin karşılaştırılması.

Hastalar kolestaz etiyolojisi belirsiz grup ayrı tutulup, kolestaz tiplerine göre, intrahepatik ve ekstrahepatik olarak 2'ye ayrıldığındaki laboratuvar değerleri Tablo 9'da detaylı olarak verilmiştir. Total bilirübin değerleri ortalamaları ekstrahepatik kolestazda intrahepatik kolestaza göre

\begin{tabular}{lcc}
\multicolumn{3}{l}{$\begin{array}{l}\text { Tablo 8. Laboratuvar değerlerinin malignite ile iliş- } \\
\text { kisini gösteren çoklu logistik regresyon analizi (n: } \\
\text { 178) }\end{array}$} \\
\hline & p & Odds Ratio \\
\hline Total bilirübin & $<0.001$ & 1.137 \\
\hline ALP & 0.001 & 1.004 \\
\hline GGT & 0.281 & 0.999 \\
\hline LDH & 0.665 & 1 \\
\hline CRP & 0.075 & 0.994
\end{tabular}

ALP: Alkalen fosfataz. GGT: Gama glutamil transferaz, LDH: Laktat dehidrogenaz, CRP: C-reaktif protein.

istatistiksel olarak anlamlı düzeyde yüksek bulundu ( $p=$ 0.002). Direkt bilirübin, ALT, ALP, GGT, sedimantasyon, CRP değerleri ortalamaları da ekstrahepatik kolestazda intrahepatik kolestaza göre istatistiksel olarak anlamlı düzeyde yüksek bulundu $(p=0.001)$. WBC değerleri ortalamaları ekstrahepatik kolestazda intrahepatik kolestaza göre istatistiksel olarak anlamlı düzeyde yüksek bulundu $(p=0.002)$ Tablo 9). 


\section{Tablo 9. Kolestaz tipine göre laboratuvar parametrelerinin karşılaştırılması ( $n=178$ )}

\begin{tabular}{|c|c|c|c|}
\hline & & & \\
\hline & $\begin{array}{c}\text { Intrahepatik } \\
n: 46\end{array}$ & $\begin{array}{c}\text { Ekstrahepatik } \\
\qquad \mathrm{n}: 132\end{array}$ & p \\
\hline Total bilirübin (mg/dl) & $3.75(2-23)$ & $6.85(2.1-31)$ & $0.002 * *$ \\
\hline Direkt bilirübin (mg/dl) & $1.5(0.15-12)$ & $4(0.2-16)$ & $0.001 * * *$ \\
\hline AST (U/L) & $91(13-1970)$ & $125(10-1002)$ & 0.163 \\
\hline $\operatorname{ALT}(U / L)$ & $46.5(11-1326)$ & $118.5(5-937)$ & $0.001 * * *$ \\
\hline $\operatorname{ALP}(U / L)$ & $181(47-1337)$ & $318.5(46-1678)$ & $0.001 * * *$ \\
\hline GGT (U/L) & $121.5(14-2204)$ & $421.5(11-2300)$ & $0.001 * * *$ \\
\hline LDH (U/L) & $288.5(158-4738)$ & $282(128-1540)$ & 0.717 \\
\hline WBC $\left(/ \mathrm{mm}^{3}\right)$ & $6500(2400-18000)$ & $9200(3400-73000)$ & $0.002 * *$ \\
\hline Sedim. (mm/saat) & $26(2-103)$ & $41.5(4-120)$ & $0.001 * * *$ \\
\hline $\mathrm{CRP}(\mathrm{mg} / \mathrm{L})$ & $21(1-214)$ & $60.5(1-306)$ & $0.001 * * *$ \\
\hline
\end{tabular}

AST: Aspartat aminotransferaz, ALT: Alanin aminotransferaz, ALP: Alkalen fosfataz. GGT: Gama glutamil transferaz, LDH: Laktat dehidrogenaz, WBC: Lökosit, Sedim: Sedimantasyon, CRP: C-reaktif protein.

185 hastanın laboratuvar parametreleri ile mortalite arasındaki ilişki incelendiğinde; exitus (9) olan grupta total bilirübin ve direkt bilirübin değerlerinin taburcu olan gruba göre istatistiksel olarak anlamlı düzeyde yüksek olduğu tespit edildi ( $p=0.037)(p=0.032)$. Diğer laboratuvar parametrelerinde ise iki grup arasında istatistiksel olarak anlamlı düzeyde fark saptanmadı.

\section{TARTIŞMA}

Kolestaz günlük pratikte çok sık gördüğümüz ve önemli bir hastalığın bulgusu olmasına rağmen, literatürde, özellikle 65 yaş üstü hastalarda kolestazın yönetimi ile ilgili yeterli veri yoktur. Literatüre göre toplumumuzda yaşlı popülasyonun yüzdesi giderek artmakta ve buna bağlı olarak da kolestaz nedeniyle hastaneye yatan hastaların büyük çoğunluğunu 65 yaş üstü hastalar oluşturmaktadır. Genel olarak kolestaz etiyolojilerini araştıran çalışmalarda hastaların ortalama yaşı 55-60 yıl arasında bulunmuştur $(10,11)$. 1960'da yapılan ve geriatrik popülasyonu içeren literatürdeki tek çalışmada yaş ortalaması belirtilmemiştir (12). 65 yaş ve üstü grupta yaptığımız çalışmamızda ise hastaların yaş ortalaması 76.5 yıl saptandı ve cinsiyetleri arasında fark yoktu.

Tüm yaş gruplarını alarak yapılan pek çok çalışmada yaşla birlikte malignitenin arttığı belirtmiştir $(13,14)$. Ancak bizim çalışmamızda benign ve malign sebeplere göre bakıldığında hastaların medyan yaşlarının eşit olduğu görüldü. Ayrıca hastalar 65-74 yaş arası, 75-84 yaş arası ve 85 yaş üstü şeklinde 3 gruba ayrılıp incelendiğinde her 3 yaş grubunda da malignite oranı benzer saptandı. Bu bize geriatrik popülasyonda da benign nedenlerin göz ardı edilmemesi gerektiğini düşündürdü. Özemir ve arkadaşları yaptıkları çalışmada koledokolitiazis hastalarının yaş ortalamalarını (57.4 yıl), periampüller tümör hastalarının yaş ortalamasından (64 yıl) düşük olduğunu saptamışlardır (11). Bu sonuçların aksine çalışmamızda koledokolitiazis saptanan hastaların yaş ortalaması (76.8 yıl), periampüller tümör saptanan hastaların yaş ortalamasından (73.1 yıl) yüksek saptandı. Bu durum artan yaş ile birlikte malign hastalıkların mortalitesinin artması ve tam tersine koledokolitiazisin daha selim, tedavi edilebilir ve mortalitesi düşük bir hastalık olması nedeniyle koledokolitiazis hastalarının yaşam sürelerinin daha uzun olmasından kaynaklanabilir.

Hastaların kolestaz etiyolojilerine bakıldığında \%58.9'unun (n: 109) benign, \%37.3'ünün ( $n$ : 69) malign, \%3.8'inin (n: 7 ) ise etiyolojisinin belirsiz olduğu saptandı. Güler ve arkadaşlarının biliyer obstrüksiyonun nedenlerini araştırmak amacıyla 18 yaş üstü erişkin popülasyonda yaptığı çalışmada hastaların \%71.2'si benign ( $\mathrm{n}$ : 99), \%28.8'i malign (n: 40) bulunmuştur. Buna karşılık, Roy BC ve arkadaşlarının yaptığı çalışmada ise hastaların \%42'si (n: 21) benign, \%58'i (n: 29) malign saptanmıştır (16). Mabula JB ve arkadaşlarının yatan hastalardaki kolestaz etiyolojisini araştırmak için yaptığı bir çalışmada ise hastaların \%37.7'sinin (n: 52) benign, \%62.3'ünün (n: 86) ise malign olduğu saptanmıştır (10). Mabula JB ve arkadaşlarının çalışmasında 
malign etiyolojilerin diğer çalışmalara göre daha yüksek olmasının sebebinin, çalışmanın genel cerrahi ve dahiliye kliniği ile birlikte yapılması ve çalısma grubunun medikal tedavi edilen benign kolestaz sebeplerini çalışmaya dahil etmemesi olabileceği düşünüldü. Bununla birlikte hastanemiz gastroenteroloji kliniğinin bulunduğumuz bölgede ERCP yapan 2 büyük merkezden biri olması ve koledokolitiazis tanısı konulan hastaların kliniğimize yönlendirilmesi çalışmamızda benign nedenlerin yüksek çıkmasına yol açmış olabilir.

Çalışmamızda en sık kolestaz sebebi koledokolitiazis olarak saptandı. Siddique K ve arkadaşları tarafından yapılan ve yaş ortalaması 49.5 olan bir çalışmada da en sık kolestaz sebebi koledokolitiazis bulunmuştur. Verma $\mathrm{S}$ ve arkadaşlarının; yaş ortalaması 50.4 olan hastalarda yaptığı başka bir çalışmada ise en sık kolestaz sebebi pankreas başı kanseri saptanmıştır (18). Fakat bu çalışmanın bir radyoloji departmanında yapılmış olması, pankreas başı kanserinin en sık etiyoloji olarak saptandığını düşündürmektedir. Çalışmamızda en sık malign kolestaz sebebi olarak kolanjioselüler karsinom (tüm hastaların \%13.5'i) saptandı. Pankreas kanseri yaşlanma ile beraber ortaya çıkan ve 50'li yaşlardan sonra sıklığı artan bir kanserdir (19). Bizim çalışmamızın geriatrik popülasyonda yapılmasına rağmen kolanjioselüler kanserin daha sık görülmesi, pankreas kanserinde teşhis yaşının daha aşağılara düştüğü tezini desteklemektedir (20).

Çalışmamızda kolestaz sebebini pankreatite bağladığımız hasta sayısı 18 (\%9.7) idi. Morse ve arkadaşlarının çalışmasında bu oran \%5.5 (12), Chalya LP ve arkadaşlarının yaptığı çalışmada \%6 (21) ve Mabula JB ve arkadaşlarının yaptığı başka bir çalışmada da \%7.6 olarak bulunmuştur (10). Pankreatit direkt olarak bir kolestaz nedeni değildir ancak enfeksiyon, inflamasyon veya koledokta oluşan obstrüksiyona bağlı olarak kolestaz gelişebilmektedir. ÇaIışmamızdaki pankreatit hastalarının hepsinde USG ve/ veya MRCP ile kolelitiazis saptanmıştı. Bu nedenle bu hastalarda kolestaz sebebinin pankreatite neden olan koledoktaki çamur veya mikrolitiazisin olabileceği düşünüldü. Etiyolojik sebep olarak siroz olan hasta sayısı 14 (\%7.6) olarak bulundu. Zhong Yu ve arkadaşlarının yaptıkları bir çalışmada bu oran \%15 saptanmıştır. Ülkemizde yapılan bilirübin düzeyi $5 \mathrm{mg} / \mathrm{dl}$ 'nin üzerinde olan hastalardaki bir çalışmada ise sarılık etiyolojisinde sirozun saptanma oranı \%10 saptanmıştır (22). Çalışmamızda kolestaz etiyolojisini sepsise bağladığımız hastalarımız tüm hastaların \%5.4'ünü oluşturuyordu. 2001 yılında İlanda'da yapılan bir çalışmada ise bilirübin düzeyi $7 \mathrm{mg} / \mathrm{dl}$ üzerinde olan hastalar çalışmaya alınmış ve hastaların \%20'sinin sarıllğındaki sebebin sepsis olduğu gözlenmiştir (23). Bu yapı- lan çalışmada sepsisin bu denli yüksek olmasının sebebi çalışma grubunun yoğun bakım hastalarını da çalışmaya dahil etmelerinden kaynaklanıyor olabilir.

Kolestazla hastaneye yatırılan hastalarımızın en sık şikayeti karın ağrısı idi. Karın ağrısı ile başvuran hastalarımızın $\% 66.4$ 'ü benign etiyolojilerdi ve bu oran malignlere göre istatistiksel olarak anlamlı düzeyde yüksekti ( $p: 0.030)$. Literatürdeki benzer çalışmalarda da karın ağrısı etiyolojisi olarak en sık benign sebepler bulunmuştur $(12,21)$. Genel popülasyonda yapılan çalışmalar ve geriatrik popülasyonda yapmış olduğumuz çalışma beraber değerlendirildiğinde, yaş ilerlese bile karın ağrısı ile başvuran hastalarda benign etiyolojiler öncelikle düşünülmelidir. Çalışmamızda 2. en sık görülen şikayet ise sarılıktı ve sarılık ile başvuran hastaların malign olma intimali istatistiksel olarak anlamlı düzeyde daha yüksekti. Bu konuda yapılan çalışmaların bazılarında karın ağrısı en sık şikayet olarak belirtilirken $(24,25)$ bazılarında da sarılık en sık başvuru şikayeti olarak bildirilmiştir $(12,18)$. Bu farklılk da etiyolojiden kaynaklanmaktadır. Bizim çalışmamızda da benign nedenlerin daha fazla olması, karın ağrısı şikayetinin sarlıktan daha fazla görülmesinin nedeni olabilir. Her ne kadar karın ağrısı benign hastalarda en sık şikayet olsa da, malign hastaların da çoğunda (69 hastanın 42'sinde) karın ağrısı şikayeti mevcuttu. Bu nedenle başvuru şikayeti karın ağrısı olan hastalarda ön planda benign nedenler düşünülürken, malign nedenler de akılda tutulmalıdır.

Çalışmamızda kilo kaybı şikayeti de sarılık gibi malign hastalarda anlamlı düzeyde yüksek bulunmuştur. Roy BJ ve arkadaşlarının yaptığı çalışmada da kilo kaybı ile başvuran hastalarda malignite tanısı istatistiksel olarak anlamlı düzeyde yüksek saptanmıştır (16). Kaşıntı şikayetiyle başvuran hastalarda ise literatüre benzer şekilde benign ve malign gruplar arasında fark saptanmamışır (17).

Laboratuvar değerleri açısından malign ve benign gruplar karşılaştıııldı̆ıında bilirübin ve ALP düzeylerinin malign grupta, CRP'nin ise benign grupta anlamlı düzeyde yüksek olduğu saptandı. Siddique ve arkadaşları, Verma $\mathrm{S}$ ve arkadaşları ve Chalya ve arkadaşları tarafından yapılan çalışmalarda malign ve benign grup arasında ALP ve bilirübin değerleri açısından istatistiksel olarak anlamlı farklılık saptanmamıştır $(17,18,21)$. Çalışmamızda benign hastalarda da ALP değerleri normelden yüksek saptandı. Mabula JB ve arkadaşlarının yaptığı bir çalışmada da ALP değeri her iki grupta da yüksek saptanmıştır (10). Çalışmamızda resgresyon analizinde en değerli laboratuvar bulguları ALP ve bilirubin yüksekliği olarak tespit edilmiştir. ROC eğrisinde total bilirübin ve direkt bilirübin için EAA \%80'in üzerinde iken ALP için altında bulunmuştur. ALP vücudun değişik organlarında salgılanan bir enzim 
olup, ALP yüksekliğine GGT ve direkt bilirübin yüksekliği de eşlik ediyorsa öncelikle kolestaz ekarte edilmelidir. Bununla birlikte, ALP değeri normal olan bir hastada da kolestaz olabileceği de akılda tutulmalıdır. Alt grup analizlerinde en yüksek CRP değerleri pankreatit hastalarında, sonra ise karaciğer metastazı ve koledokolitiazis saptanan hastalarda görülmüştür. CRP değerlerinin enfeksiyon ve inflamasyon durumlarında yüksek saptanması literatürle uyumludur (26).

Kolestazın intrahepatik ve ekstrahepatik nedenlerine göre laboratuvar değerlerini karşllaştırdığımızda; bilirübin, ALT, ALP, GGT, WBC, sedimantasyon ve CRP değerleri ekstrahepatik kolestazlı hastalarda anlamlı derecede yüksek bulunmuştur. Inflamatuvar göstergelerin ekstrahepatik kolestazda daha yüksek çıkması, hastaların \%40'ını oluşturan koledokolitiazis ve buna bağlı kolanjitlerle, pankreatitlerin bu grupta olmasından kaynaklanmış olabileceği düşünüldü. Laboratuvar parametrelerinden sadece bilirübin düzeyinin yüksek olması mortalite ile ilişkili bulundu. Çalışmamızda ex olan hastaların total bilirübin değerleri ortalamaları $11 \mathrm{mg} / \mathrm{dl}$ olup diğer hastalara göre istatistiksel olarak anlamlı düzeyde yüksek saptandı. Pitiakoudis ve arkadaşları da tüm yaş gruplarını içeren ve yaş ortalaması 59 olan, kolestazlı yatan hastalarda yaptıkları çalışmada; bilirübin düzeyi 20'den büyük olanların mortalitesinin 20'den düşük olanlara göre yüksek olduğunu saptamışlardır (27). Yine aynı çalışmada saptanan, ALP ve WBC yüksekliğinin de mortalite ile ilişkili olma durumu ise bizim çalışmamızda saptanmadı. Bilirübin düzeyi yüksekliğinin mortalite ile ilişkisi olduğuna dair literatürde pek çok çalışma bulunmaktadır $(10,21)$.

Hastalarımızın tamamına USG yapıldı ve \%88.6'sında USG'nin obtrüksiyonu saptadığı ancak \%47.7'sinde USG ile tanı konulabildiği gözlendi. Malign sebeplerin $\% 50.7$ 'sine, benign sebeplerin \%45.8'ine USG ile tanı koyuduğu görüldü. Literatüre bakıldığında USG'nin safra kanalındaki problemleri yakalama olasılığı \%90-95 gibi yüksek değerler iken (28), kesin tanı koyma olasılığı ise yapılan çeşitli çalışmalarda \%21-63 arasında saptanmışırı (29). Sonuçların bu kadar farklı olmasının nedeni USG'nin uygulayıcı kişiye bağlı bir yöntem olmasından ve hasta ile ilgili birtakım özelliklerden kaynaklanabilir. Özellikle yaş ortalaması daha genç olan hasta gruplarında yapılan çalışmalarda USG'nin tanı koyduruculuğunun daha yüksek saptanması $(21,28)$ genç hastalarda USG esnasında kooperasyon probleminin olmamasından ve yine yaşla birlikte artan obeziteye bağlı görüntü kalitesinin azalmasından kaynaklanıyor olabilir. Çalışmamızda en sık etiyolojik sebep olarak bulduğumuz koledokolitiazisi USG'nin saptama olasılığı literatürle uyumlu olarak \%50 civarında bulundu (24). Oranın bu seviyelerde kalması distal koledoğun görüntülenmesindeki güçlüklerden, 3 mm'den küçük koledok taşlarından (mikrolitiazis) ve hastaların pek çoğunda gözlenen bağırsak gazlarından kaynaklanıyor olabilir. Çalışmamızda USG ile tanı koyamadığımız 100 hastada ileri inceleme yöntemleri kullanıldı ve bunların 93'üne daha tanı konarak toplam 178 hastanın (\%96.2) tanısı belirlenmiş oldu. Tanı konamayan 7 hastadan (\%3.8) 4 hasta dış merkeze EUS'a yönlendirilirken 3'ünün ise takipte tamamen düzeldiği gözlendi.

Çalışmamızda geriatrik popülasyonda kolestaz etiyolojisinde benign sebepler daha sık görülmekle birlikte malign sebeplerin de prevalansı oldukça yüksek saptanmıştır. Benign nedenlerden koledokolitiyazis en sık sebep iken, kolanjiyosellüler kanser en sık malign sebep olarak bulunmuştur. Hastaneye başvuru şikayeti sarılık ve kilo kaybı olan ve/veya bilirübin ve ALP düzeyi yüksek olan hastalarda malign hastalıklar ön planda düşünülmelidir. Total bilirübin 7 ve direkt bilirübin $4.1^{\prime}$ in üstü malign ve benign kolestaz etiyolojilerinin ayrımında en önemli laboratuvar göstergesi olarak bulunmuştur. Ayrıca bilirübin yüksekliğinin mortalitenin en önemli göstergesi olduğu saptanmıştır. USG geriatrik popülasyondaki kolestazlı hastalarda tanı koymada yetersiz bulunmuş ve ileri görüntüleme tetkiklerine (BT, MR, MRCP, ERCP, EUS gibi) intiyaç olmuştur.

Sonuç olarak geriatrik hastalarda benign etiyolojiler daha sık saptansa da, çalışmamızda olduğu gibi malignite göstergesi olabilecek şikayet ve laboratuvar sonuçlarına dikkat edilmeli, ultrasonografinin tanısal yönden zayıf kaldığı akılda tutulmalıdır.

Etik Kurul: Çalısma Helsinki Deklerasyon Prensiplerine uygun şekilde yapılmıştır. Bu araştırma retrospektif olarak tasarlanmış klinik bir çalışmadır. Etik kurul onayı Sağlık Bilimleri Üniversitesi Antalya Eğitim ve Araştırma Hastanesi Etik Kurulu'ndan alınmıştır (Karar No: 24.03.2016/76-3).

Çıkar Çatışması: Yazarlar, makalenin yazımı ve basımı açışından çıkar çatışması beyan etmemektedirler.

Finansal Destek: Bu çalışma için finansal destek alınmamıştır. 


\section{KAYNAKLAR}

1. Heathcote EJ. Diagnosis and management of cholestatic liver disease. Clin Gastroenterol Hepatol 2007;5:776-82.

2. Trauner M, Meier PJ, Boyer JL. Molecular pathogenesis of cholestasis. N Engl J Med 1998;339:1217-27.

3. European Association for the Study of the L. EASL Clinical Practice Guidelines: management of cholestatic liver diseases. J Hepatol 2009;51:237-67.

4. Solter PF. Clinical pathology approaches to hepatic injury. Toxicol Pathol 2005;33:9-16.

5. Khan SS, Singer BD, Vaughan DE. Molecular and physiological manifestations and measurement of aging in humans. Aging Cell 2017; 16:624-33.

6. Mattiuzzi C, Lippi G. Worldwide disease epidemiology in the older persons. Eur Geriatr Med 2020;11:147-53.

7. Ogura S, Jakovljevic MM. Editorial: Global Population Aging Health Care, Social and Economic Consequences. Front Public Health 2018;6:335.

8. Russo CA, Elixhauser A. Hospitalizations in the Elderly Population, 2003: Statistical Brief \#6. Healthcare Cost and Utilization Project (HCUP) Statistical Briefs. Rockville (MD): Agency for Healthcare Research and Quality (US); 2006 Feb.

9. Leandros E, Alexakis N, Archontovasilis F, et al. Outcome analysis of laparoscopic cholecystectomy in patients aged 80 years and older with complicated gallstone disease. J Laparoendosc Adv Surg Tech A 2007; 17:731-5.

10. Mabula JB, Gilyoma JM, McHembe MD, et al. Predictors of outcome among patients with obstructive jaundice at Bugando Medical Centre in north-western Tanzania. Tanzan J Health Res 2013;15:216-22.

11. Ozemir IA, Buyuker F, Gurbuz B, et al. An Educational Clinic's Experiences On Diagnosis And Treatment Of Patients With Obstructive Jaundice. Marmara Medical Journal. 2010;24:119-22.

12. Morse TS, Deterling RA Jr. Obstructive jaundice in the elderly patient. Am J Surg 1962;104:587-90.

13. Chalya PL, Kanumba ES, McHembe M. Etiological spectrum and treatment outcome of Obstructive jaundice at a University teaching Hospital in northwestern Tanzania: A diagnostic and therapeutic challenges. BMC Res Notes 2011;4:147.

14. Aziz M, Ahmad N, Faizullah. Incidence of malignant Obstructive Jaundice - a study of hundred patients at Nishtar Hospital Multan. Annals of King Edward Medical University. 2016;10 (1).

15. Guler O, Aras A, Aydin M, et al. Biliyer Obstrüksiyon Nedenleri ve Uygulanan Tedaviler; 139 Olguluk Seri. 2000;7:10-5.
16. Roy C, Hanifa A, Alam S, Naher S, Sarkar P. Etiological spectrum of obstructive jaundice in a tertiary care hospital. Global Journal of Medical Research. 2015;15:1-5.

17. Siddique K, Ali Q, Mirza S, et al. Evaluation of the aetiological spectrum of obstructive jaundice. J Ayub Med Coll Abbottabad 2008;20:62-6.

18. Verma S, B.Sahai S, K.Gupta P. Title of the article: Obstructive jaundice-aetiological spectrum, clinical, biochemical and radiological evaluation at a tertiary care teaching hospital. Internet Journal of Tropical Medicine 2011;7.

19. Feldman M, Friedman LS, Brandt LJ. Sleisenger and Fordtran's Gastrointestinal and Liver Disease E-book: Pathophysiology, Diagnosis, Management: Elsevier; 2020.

20. Neki NS. Jaundice in elderly. Journal of Medical Education and Research 2013;15:113-16.

21. Chalya PL, Kanumba ES, McHembe M. Etiological spectrum and treatment outcome of Obstructive jaundice at a University teaching Hospital in northwestern Tanzania: A diagnostic and therapeutic challenges. BMC Res Notes 2011;4:147.

22. Altıntaş E, Tombak A, Tellioğlu B. The causes, diagnosis and treatment of severe jaundice. Akademik Gastroenteroloji Dergisi 2010;9:2-7.

23. Whitehead MW, Hainsworth I, Kingham JG. The causes of obvious jaundice in South West Wales: perceptions versus reality. Gut 2001;48:409-13.

24. Moghimi M, Marashi SA, Salehian MT, et al. Obstructive jaundice in Iran: factors affecting early outcome. Hepatobiliary Pancreat Dis Int 2008;7:515-9.

25. Bekele Z, Yifru A. Obstructive jaundice in adult Ethiopians in a referral hospital. Ethiop Med J 2000;38:267-75.

26. Wu Y, Potempa LA, El Kebir D, Filep JG. C-reactive protein and inflammation: conformational changes affect function. Biol Chem 2015;396:1181-97.

27. O'Connor OJ, O'Neill S, Maher MM. Imaging of biliary tract disease. AJR Am J Roentgenol 2011;197:W551-8.

28. Farrukh SZ, Siddiqui AR, Haqqi SA, et al. Comparison of ultrasound evaluation of patients of obstructive jaundice with endoscopic retrograde cholangio-pancreatography findings. J Ayub Med Coll Abbottabad 2016;28:650-2.

29. Stott MA, Farrands PA, Guyer PB, et al. Ultrasound of the common bile duct in patients undergoing cholecystectomy. J Clin Ultrasound 1991;19:73-6. 